\title{
THE EFFECT OF HIPPOTHERAPY ON GAIT IN PATIENTS WITH SPASTIC CEREBRAL PALSY
}

\author{
Veronika Fízková, Eva Krejčí, Zdeněk Svoboda*, Milan Elfmark, Miroslav Janura
}

Faculty of Physical Culture, Palacký University, Olomouc, Czech Republic

Submitted in October, 2013

\begin{abstract}
BACKGROUND: Disorders of motor skills, especially regarding gait, are prevalent in nearly all forms of cerebral palsy. Through a horse's back movement, the patient is exposed to proprioceptive stimulation, thus improvement in gait performance could be expected.

OBJECTIVE: The aim of our study was to determine the effect of hippotherapy on gait in patients with spastic cerebral palsy

METHODS: Eleven subjects (age $14.3 \pm 4.8$ years, height $148.2 \pm 17.6 \mathrm{~cm}$, weight $43.3 \pm 20.2 \mathrm{~kg}$ ) with spastic cerebral palsy participated in the study. Gait assessment was performed before and after a weeklong stay. The hippotherapy was conducted daily. Kinematic data from three trials for each child was obtained using the Vicon MX system (seven infrared cameras, frequency $200 \mathrm{~Hz}$ ). Comparison of ankle, knee, hip and pelvis movement before and after hippotherapy intervention was performed in Statistica (version 10.0) using the Wilcoxon test. To determine the effect size, Cohen's $d$ was used.

RESULTS: After completing the short-term hippotherapy intervention, we observed a decrease in the second plantar flexion during initial swing $(p<.05)$, decrease in knee flexion during the stance phase $(p<.05)$, decrease in the hip range of motion in sagittal plane $(p<.05)$ and decrease in the pelvic obliquity $(p<.05)$. The effect size for all statistically significant differences was low.

CONCLUSIONS: Hippotherapy combined with individually defined physiotherapy can lead to some changes in bipedal locomotion in terms of improvement and thus contribute to greater self-sufficiency, self-reliance and independence of patients with cerebral palsy.
\end{abstract}

Keywords: Physiotherapy, walking, horse, equine assisted therapy, cerebral palsy.

\section{INTRODUCTION}

Cerebral palsy (CP) is one of the most common childhood neuromuscular disease. Basically, it is permanent brain damage (also damage to the spinal cord to a lesser degree) of a non-progressive nature arising prenatally, perinatally or postnatally within the first year of the child's birth, followed by a prevailing disorder of motor and postural functions (Komárek \& Zumrová, 2008). One of the main symptoms of this disease is spasticity limiting the mobility of individuals within the normal range of movement, which can later lead to deformities and contractures (Talic \& Honemeyer, 2010). In order to improve the quality of life of people with $\mathrm{CP}$, it is necessary to apply a very comprehensive and multidisciplinary approach with emphasis on appropriate reha-

\footnotetext{
* Address for correspondence: Zdeněk Svoboda, Department of Natural Sciences in Kinanthropology, Faculty of Physical Culture, Palacký University, tř. Míru 115, 77111 Olomouc, Czech Republic. E-mail: zdenek.svoboda@upol.cz
}

bilitation (Liptak, 2005; Oppenheim, 2009). Inclusion of hippotherapy into the rehabilitation programme may be one of the ways leading to improvement in the motor skills of people with CP.

Hippotherapy uses three-dimensional motion stimuli that are transmitted to the patient from the back of a walking horse (Schwesig et al., 2009). Through continual movement of the centre of gravity in the rhythm of a walking horse, the patient is exposed to proprioceptive stimulation to which he/she must continually adapt. This leads to changes in the setting of global motor patterns and subsequent improvements, especially in the area of gross motor skills, postural control and stability (Jiskrová, Casková, \& Dvořáková, 2009). Hippotherapy can be indicated in all forms of $\mathrm{CP}$, however greater successes are seen in patients with spastic forms of cerebral palsy. In children with $\mathrm{CP}$, the perception of rhythmic movements of the horse leads to improved dynamic postural stability, the conscious and feedback postural control (Haehl, Giuliani, \& Lewis, 1999; Shurtleff, Standeve, \& Engsberg, 2009; 
Sterba, Rogers, France, \& Vokes, 2002). Hornáček, Kafková, and Páleníková (2010) note the strong and intense effects of hippotherapy on postural-locomotor functions in people with spastic quadriplegic cerebral palsy, particularly within the first and up to the tenth hippotherapy unit.

In children with cerebral palsy, gait is quite variable but similarities in the pathological features can be found. Individual differences in gait patterns relate to the topography of the lesion and its extent (Winters, Gage, \& Hicks, 1987). Using hippotherapy, these pathological patterns can be reduced. Hippotherapy favourably affects muscle asymmetry of the lower limb muscles (Benda, McGibbon, \& Grant, 2003; Kulichová \& Böswart, 1995; McGibbon, Andrade, Widener, \& Cintas, 1998; McGibbon, Benda, Duncan, \& Silkwood-Sherer, 2009). Despite the conflicting results of some studies (Drnach, O’Brien, \& Kreger, 2010; Hamill, Washington, \& White, 2007), the authors assume that any pertinent improvements in the gross motor skills score due to hippotherapy may ultimately lead to reduction in the degree of motor impairment in children with CP. They also agree that it is necessary to carry out further studies dealing with gait in persons with cerebral palsy.

The basic tool for quantitative gait evaluation is kinematic analysis, which enables to assess differences in gait performance in basic joints an in all three planes. In the scientific literature, there is a lack of studies concerning the effect of hippotherapy in CP children.

The aim of our study was to determine the effect of hippotherapy on gait in patients with spastic cerebral palsy.

\section{METHODS}

\section{Measured set}

Based on the assessment of preconditions for the walk, the study included 11 subjects (age $14.3 \pm 4.8$ years, height $148.2 \pm 17.6 \mathrm{~cm}$, weight $43.3 \pm 20.2 \mathrm{~kg}$ ). The criterion for inclusion in the test set was confirmed cerebral palsy diagnosis with the following types of disability: spastic - diparesis, triparesis, quadruparesis as well as hypotonic syndrome with a hint of onset spasticity. Each tested individual had to be able to walk independently without using any assistive aids.

\section{Instrumentation}

To record the movement and to determine the basic kinematic gait parameters, we used optoelectronic Vicon MX system (Vicon Motion Systems, London, UK). The gait recordings were performed using seven infrared cameras (type T10, frequency $200 \mathrm{~Hz}$, resolution $1000 \times 1000$ pixels) enabling the recording of reflective points located at selected places on the body.

\section{Preparation and measurement}

Before starting the analysis, the anthropometric measurements of selected body segments (width of the ankle and knee, functional length of the lower extremities) of the subjects was performed. After these measurements, 16 reflective markers (Plug-In Gait model) were placed bilaterally on the body to the following positions: anterior superior iliac spine, posterior superior iliac spine, thigh, knee (lateral epicondyle), shank, ankle (lateral malleolus), heel and toe (2nd metatarsal head). Children performed their walking trials with their normal shoes, because without shoes some of them were not able to walk. The presence of shoes and clothes also contributed to natural and comfortable gait performance in observed children. To reduce this effect conditions (shoes, clothes) were the same in both measurements and position of the markers was determined by the same person.

Measurements were carried out under standard conditions at $23^{\circ} \mathrm{C}$ within the course of about 6 metres. Each of the subjects completed 3-5 walking trials with his/her natural speed in the period prior to hippotherapy intervention. The second measurement in the same extent was performed after a week's stay with the daily application of the hippotherapy unit.

\section{Hippotherapy intervention}

For the purpose of this work, we cooperated with hippo-rehabilitation associations Piafa in Vyškov and EPONA, o. s., from Brno. These associations offer hippotherapy to children with cerebral palsy during stays on site where the therapeutic horses are stabled.

The hippotherapy itself took place in a quiet forest environment in the presence of a professional team composed of a horse leader, a physiotherapist and an educator. During hippotherapy, the horse walked about $1.5 \mathrm{~km}$ on a flat terrain; the trajectory also led among trees in a short section (figure-eights) where a slight incline with minor surface imperfections had to be overcome. The therapy was carried out in good weather conditions. The most common positions during hippotherapy were: classic sitting, the stimulus position by lying prone and assisted sitting with the support of a physiotherapist. In single positions, the subjects were facilitated by various pedagogical aids, by reaching objects, handling the objects and tactile stimulation with or without aids.

Hippotherapy was performed using specially trained horses "tailored" to the subjects. The following breeds were involved: Silesian noriker, Lipnicki horse, Haflinger, the Czech warm-blooded horse and the Czech-Moravian Belgian horse. One hippotherapy unit lasted 30 minutes, including the psychological preparation of the child, mounting and adjustment of the child to the position based on the developmental 
kinesiology. During the weeklong stay, hippotherapy as a key method was indicated daily. In addition to hippotherapy, the subjects underwent canistherapy and individually prescribed physiotherapy.

\section{Measured parameters}

All angle variables were determined from Plug-In Gait model. In this case normalization to standing was not used. In the sagittal plane, maximal values of first plantar flexion, dorsal flexion, second plantar flexion, knee flexion during stance phase, knee extension during stance phase, knee flexion during swing phase, knee extension during swing phase, hip flexion, hip extension, pelvic anteversion and pelvic retroversion were assessed. In the frontal and transversal planes maximal and minimal values of ankle, knee, hip and pelvis were assessed.

\section{Data processing}

Of the total number of attempts measured for the purposes of this study, we analyzed and processed three valid attempts before and three valid attempts after the hippotherapy intervention. Gait kinematics were processed using the Vicon Nexus (Vicon Motion Systems, Oxford, UK). The data obtained was then exported to the Vicon Polygon (Vicon Motion Systems, Oxford, UK) and subsequently processed using Microsoft Office Excel. Statistical data processing was done in Statistica (version 10.0, StatSoft, Inc., Tulsa, OK, USA). Nonparametric paired Wilcoxon test was used to determine the differences between single kinematic gait parameters. Hypotheses were tested for statistical significance level of $\alpha<.05$. To determine the effect size, Cohen's $d(0.2<d<0.5$ - small effect; $0.5<d<0.8$ - moderate effect; $0.8<d$ - large effect) was used (Cohen, 1988).

\section{RESULTS}

Basic statistical characteristics of variables that significant differences between measurements before and after hippotherapy intervention are presented in Table 1.

\section{Ankle}

In the sagittal plane, after completing the short-term hippotherapy intervention, we observed a decrease in the maximum of plantar flexion during initial swing $(p<.05)$ and prolongation of the time needed to achieve the maximum plantar flexion during loading response $(p<.05)$. The effect size was low for both differences.

\section{Knee}

In the sagittal plane, after completing the short-term hippotherapy intervention, we observed a reduction in flexion at the knee joint during the stance phase $(p<.05)$. The effect size was low. We did not find any statistically significant difference $(p<.05)$ for the time parameters of the knee joint kinematics with regard to any of the observed planes.

\section{Hip}

In the sagittal plane, after completing the short-term hippotherapy intervention, we observed reduction in the total range of motion at the hip joint $(p<.01)$ and in the time needed to achieve the maximum internal rotation of the hip joint during the stance phase $(p<.05)$. The effect size was low for both differences.

\section{Pelvis}

After completing the short-term hippotherapy intervention, we observed decrease in the total range of pelvic movement in the frontal plane $(p<.05)$. The effect extent was low. With regard to the time parameters characterizing pelvic movement during the gait cycle, there was no statistically significant difference $(p<.05)$ in any of the observed planes.

Table 1

Means and standard deviations of observed variables with significant difference

\begin{tabular}{lllcccc}
\hline $\begin{array}{l}\text { Joint } \\
\text { (segment) }\end{array}$ & Plane & Variable & Before & After & $p$ value & Cohen's $d$ \\
\hline Ankle & Sagittal & First maximal plantar flexion $\left(^{\circ}\right)$ & $-5.5 \pm 14.7$ & $-3.8 \pm 17.3$ & .042 & 0.300 \\
& Sagittal & $\begin{array}{l}\text { Time of first maximal plantar flexion } \\
\text { \% of gait cycle) }\end{array}$ & $3.1 \pm 2.3$ & $3.7 \pm 2.4$ & .043 & 0.338 \\
& & & & & \\
Knee & Sagittal & Maximal flexion during stance phase $\left(^{\circ}\right)$ & $40.3 \pm 13.6$ & $36.1 \pm 15.2$ & .048 & 0.291 \\
Hip & Transversal & $\begin{array}{l}\text { Time of maximal internal rotation } \\
\text { (\% of gait cycle) }\end{array}$ & $80.1 \pm 13.5$ & $74.7 \pm 14.6$ & .021 & 0.348 \\
& Transversal & Range of motion $\left(^{\circ}\right)$ & $19.6 \pm 9.8$ & $15.1 \pm 9.5$ & .006 & 0.408 \\
Pelvis & Frontal & Range of motion $\left({ }^{\circ}\right)$ & $8.7 \pm 2.8$ & $7.3 \pm 2.6$ & .015 & 0.351 \\
\hline
\end{tabular}




\section{DISCUSSION}

To avoid complications in children with $\mathrm{CP}$, it is important to start the treatment in a timely and proper manner. Hippotherapy inclusion in a comprehensive rehabilitation scheme for children with cerebral palsy can, therefore, have significant benefits, particularly in the areas of postural and locomotor programmes that are mostly affected in such children (Hornáček et al., 2010).

As a common feature of various forms of $\mathrm{CP}$, we can mention disorders in the area of postural control that originate on the basis of abnormal neurophysiological mechanisms. The presence of disorders of muscle synergies does not allow a person to carry out targeted movements. These persons show changes in muscle synergies or muscle timing even when standing (Ferdjallah, Harris, Smith, \& Werich, 2002). During walking, such changes are more pronounced due to higher demands on the control of postural muscles. Hsue, Miller, and Su (2009) found that changing muscle activity, in terms of increase, may represent certain strategies for maintaining an upright posture and forward movement. According to the study by Prosser, Lee, VanSant, Barbe, and Lauer (2010), increased muscle activity prevails almost throughout the gait cycle in children with bilateral spastic CP. This increased muscle activity can create a functionally rigid body, which in turn may limit the ability to adjust the position of the body with respect to the lower limbs. This situation is regarded to be highly disadvantageous, limiting volitional movements, with considerable impacts on the cardiovascular system (Woolacott, Jensen, Jasiewicz, Roncesvalles, \& Sveistrup, 1998). Based on the results of studies dealing with postural control and stability in persons with cerebral palsy, the positive contribution of hippotherapy to this area is really unique. This has been proven by the studies of Bertoti (1988), Haehl et al. (1999) and Shurtleff et al. (2009), which describe improvements in the overall posture, motor control of the body and head position in children with cerebral palsy after hippotherapy application.

Another common feature of various forms of $\mathrm{CP}$ is represented by disorders in the area of gross motor skills, especially walking. The gait in children with cerebral palsy is highly variable, but analogous pathological patterns can be found. In case of spastic diplegia, the most common pathological gait pattern is the so-called "jump gait" characterized by spasticity of the lower limbs flexors with equine position of the foot. Regarding the spastic tetraplegic form, we can often find a pathological gait pattern called "crouch gait", which is characterized by bilateral disabilities of lower limbs with typical foot position in dorsal flexion in combination with excessive knee flexion, adduction and internal rotation of the hip (Perry, 1992; Rodda \& Graham,
2001). When monitoring this area, most authors have persuaded the same view that hippotherapy positively affects muscle asymmetry in the lower limbs (Benda et al., 2003; Kulichová \& Böswart, 1995; McGibbon et al., 2009). In children with CP, the hippotherapy also has a favourable effect on the step length and frequency. McGibbon, Andrade, Widener, and Cintas (1998), Sterba et al. (2002) and Drnach et al. (2010) were assessing the gross motor skills and reported improvements after applying hippotherapy. On the contrary, studies by Hamill et al. (2007) and Rosenbaum (2009) did not prove any positive effect on gross motor skills due to hippotherapy in people with cerebral palsy.

In our study, we observed decrease in maximum plantar flexion at the end of the stance phase of the gait cycle following hippotherapy. At this phase, proper function of calf muscles is very important since they accelerate forward movement (Véle, 2006). Insufficiency of these muscles leads to delays in lifting the heel; from the kinetic point of view, flexion torque is reduced. Thus this change can be assessed as negative influence of intervention.

The knee joint is one of the major predisposing factors for stability and mobility of the physiological gait pattern (Perry, 1992). Its abnormal setting disturbs especially the stance phase of the gait cycle. Most often, it is a flexion contracture preventing the action of functional pair (flexion and extension) of the knee joint. This increases the magnitude of the flexion torque for the hip and ankle joints. Within further progression of motion, these flexion torques must be compensated at the level of other joints of the lower limbs (Gage, 1991). As for the knee joint area in the observed group of children after hippotherapy intervention, we found change in the range of maximum flexion during the stance phase. During this phase, the flexion position of the joint was reduced, which essentially indicates the expected impact of hippotherapy intervention on influencing the knee joint flexor group in favour of moving forward. With regard to the studied persons and based on this fact, we can conclude that the feedback control of the group of muscles ensuring this movement was improved and that the absorption of impact energy was reduced (Perry, 1992; Perry \& Burnfield, 2010).

The most considerable changes in the hip joint angle parameters were observed in the transversal plane. After applying the therapy, a decrease in internal-rotational position at the hip joint with a strong drive to external rotation was observed in all individuals pursued. This change may be due to normalization of muscular tonus or reduction of spasticity, particularly the adductor groups of muscles of the lower limbs. This effect has been confirmed in a study by Bertoti (1988) where hypertonus of the adductor and extensor muscle groups of the lower limbs in children with cerebral 
palsy decreased after the hippotherapy units were applied. McGibbon et al. (2009) also found that even a ten-minute therapy brings changes in the asymmetry of adductor group that have influence on the biomechanics of movement when running and jumping. The influence of hippotherapy on these muscle groups must be assessed comprehensively because hippotherapy not only suppresses the driving pathological stereotypes but also facilitates postural reflex mechanisms at the subcortical level. In the frontal plane, we observed a change in the range of pelvic obliquity in terms of its reduction. This change can be explained through the facilitatory effects of hippotherapy especially for $\mathrm{m}$. gluteus medius and m. gluteus minimus. This abductor group of muscles, together with coordinated contraction of the adductor group of muscles, ensures laterolateral stability of the pelvis in the frontal plane (Perry, 1992). The effect of hippotherapy on improving stability when standing and when walking in the lateral and anteroposterior direction is also shown by Kulichová and Böswart (1995).

\section{Limitations of the study}

The test set included only individuals with bilateral spastic form of CP selected from the original set. Despite this fact, the observed group showed differences in the size of lesion range mainly manifested in motor skills.

The output of motion stereotype depends on the amount of afferent information coming from the external or internal environment. Therefore, the presence of comorbidities in the measured children (such as visual impairments) can be considered as one of the limitations. The other possibilities of influencing the outcome are represented by the performed surgical interventions: tenotomy and prolongation of adductor tendons, knee flexors and Achilles tendons that were present in 4 subjects from a total of 11 individuals. A possible cause of the differences found could also be the different age of the individuals - although the study by Prosser et al. (2010) states that the age of children is not as important as the walk time (experience in walking). One of the limitations consisted in determining the walking speed during the measurement. When recording the motion, the walking speed was proportional to the age and the extent of disability. Each of the subjects walked with his/her natural walking speed.

Gathering data from two different centres (Radíkov and Březejc) may be another factor influencing the result. Although hippotherapy intervention during the camping period was almost identical, there could be factors influencing the process and thus also the final effect of hippotherapy. Another important factor is rehabilitation programme. The results have to be considered as result of all rehabilitation procedures.
Within this work, we can consider some of the large range of variables (Dvořáková, Janura, Svoboda, \& Dvoráková, 2010) such as the impact of the leader on the horse's walk, the influence of external environment, weather and wind conditions, surface quality and the nature of the terrain.

\section{CONCLUSION}

Despite the above-mentioned limitations, the results suggest that hippotherapy combined with individually defined physiotherapy leads to improvement in bipedal locomotion in terms of improvement and thus contribute to greater self-sufficiency, self-reliance and independence of patients with cerebral palsy. Further investigation is therefore needed to prove that hippotherapy should become an integral part of a comprehensive lifelong treatment for this group of people.

\section{ACKNOWLEDGMENT}

The study has been supported by the research grant from the Ministry of Education, Youth and Sports of the Czech Republic (No. MSM 6198959221) "Physical activity and inactivity of the inhabitants of the Czech Republic in the context of behavioral changes" and internal grant of the Faculty of Physical Culture at Palacký University in Olomouc (No FTK_2011_027) "The assessment of the impact of hippotherapy on motor patterns and psychic function re-educating of patients with cerebral palsy“.

Warm thanks belong to the associations Piafa in Vyškov and EPONA, o. s., from Brno for allowing the study to be performed in their stays.

\section{REFERENCES}

Benda, W., McGibbon, N. H., \& Grant, K. L. (2003). Improvements in muscle symmetry in children with cerebral palsy after equine-assisted therapy (hippotherapy). Journal of Alternative and Complementary Medicine, 9, 817-825.

Bertoti, D. B. (1988). Effect of therapeutic horseback riding on posture in children with cerebral palsy. Physical Therapy, 68, 1505-1512.

Cohen, J. (1988). Statistical power analysis for the behavioral sciences (2nd ed.). New York, NY: Academic Press.

Drnach, M., O'Brien, P. A., \& Kreger, A. (2010). The effects of a 5-week therapeutic horseback riding program on gross motor function in a child with cerebral palsy: A case study. The Journal of Alternative and Complementary Medicine, 16, 1003-1006.

Dvořáková, T., Janura, M., Svoboda, Z., \& Dvořáková, J. (2010). Faktory ovlivňující proces a výsledný 
efekt v hipoterapii [Factors influencing the process and resulting effect in hippotherapy]. Rehabilitace a fyzikální lékařství, 17, 188-193.

Ferdjallah, M., Harris, G. F., Smith, P., \& Werich, J. J. (2002). Analysis of postural control synergies during quiet standing in healthy children and children with cerebral palsy. Clinical Biomechanics, 17, 203-210.

Gage, J. R. (1991). Gait analysis in cerebral palsy. Oxford: Mac Keith Press.

Haehl, V., Giuliani, C., \& Lewis, C. (1999). Influence of hippotherapy on the kinematics and functional performance of two children with cerebral palsy. Pediatric Physical Therapy, 11, 89-101.

Hamill, D., Washington, K., \& White, O. R. (2007). The effect of hippotherapy on postural control in sitting for children with cerebral palsy. Physical \& Occupational Therapy in Pediatrics, 27(4), 23-42.

Hornáček, K., Kafková, A., \& Páleníková, A. (2010). Pôsobenie hipoterapie na rôzne posturálne lokomočné funkcie pri spastickej kvadruparetickej forme detskej mozgovej obrny [Influence of hippotherapy on the different postural-locomotion functions of patients with spastic quadruparetic form of cerebral palsy]. Lekársky obzor, 59, 282-286.

Hsue, B. J., Miller, F., \& Su, F. C. (2009). The dynamic balance of the children with cerebral palsy and typical developing during gait. Part I: Spatial relationship between COM and COP trajectories. Gait \& Posture, 29, 456-470.

Jiskrová, I., Casková, V., \& Dvořáková, T. (2010). Hiporehabilitace [Hipporehabilitation]. Brno: Mendelova univerzita v Brně.

Komárek, V., Zumrová, A., Glosová, L., Chamoutová, K., Kraus, J., Paděrová, K., ... Seeman, P. (2008). Dětská neurologie [Child's neurology]. Praha: Galén.

Kulichová, J., \& Böswart, J. (1995). Zhodnocení výsledků terapeutického ježdění u skupiny pacientů s dětskou mozkovou obrnou pomocí stabilografie [Assessment of result of therapeutic riding in group of patients with cerebral palsy by stabilography]. Rehabilitace a fyzikální lékařství, 2, 172-175.

Liptak, G., S. (2005). Complementary and alternative therapies for cerebral palsy. Mental Retardation and Developmental Disabilities, 11, 156-163.

McGibbon, N. H., Andrade, C. K., Widener, G., \& Cintas, H. L. (1998). Effect of an equine-movement therapy program on gait, energy expenditure, and motor function in children with spastic cerebral palsy: A pilot study. Developmental Medicine \& Child Neurology, 40, 754-762.

McGibbon, N. H., Benda, W., Duncan, B. R., \& Silkwood-Sherer, D. (2009). Immediate and long-term effects of hippotherapy on symmetry of adductor muscle activity and functional ability in children with spastic cerebral palsy. Archives of Physical Medicine and Rehabilitation, 90, 966-974.

Oppenheim, W. L. (2009). Complementary and alternative methods in cerebral palsy. Developmental Medicine \& Child Neurology, 51(4), 12-29.

Perry, J. (1992). Gait analysis: Normal and pathological function. Thorofare, NJ: SLACK.

Perry, J., \& Burnfield, J. M. (2010). Gait analysis: Normal and pathological function (2nd ed.). Thorofare, NJ: SLACK.

Prosser, L. A., Lee, S. C. K., VanSant, A. F., Barbe, M. F., \& Lauer, R. T. (2010) Trunk and hip muscle activation patterns are different during walking in young children with and without cerebral palsy. Physical Therapy, 90, 986-997.

Rodda, J., \& Graham, H. K. (2001). Classification of gait patterns in spastic hemiplegia and spastic diplegia: A basis for management algorithm. European Journal of Neurology, 5(Suppl. 5), 98-108.

Rosenbaum, P. A. (2009). Randomized controlled trial of the impact of therapeutic horse riding on the quality of life, health, and function of children with cerebral palsy. Developmental Medicine \& Child Neurology, 51, 88.

Schwesig, R., Neumann, S., Richter, D., Kauert, R., Becker, S., Esperer, H. D., \& Leuchte, S. (2009). Impact of therapeutic riding on gait and posture regulation. Sportverletz Sportschaden, 23, 84-94.

Shurtleff, T. L., Standeven, J. W., \& Engsberg, J. R. (2009). Changes in dynamic trunk/head stability and functional reach after hippotherapy. Archives of Physical Medicine and Rehabilitation, 90, 11851195.

Sterba, J. A., Rogers, B. R., France, P. A., \& Vokes, D. A. (2002). Horseback riding in children with cerebral palsy: Effect on gross motor function. Developmental Medicine \& Child Neurology, 44, 301-308.

Talic, A., \& Honemeyer, U. (2010). Cerebral palsy: State of art. Donald School Journal of Ultrasound in Obstetrics and Gynecology, 4, 189-198.

Véle, F. (2006). Kineziologie. Praha: Triton.

Winters, T. F., Gage, J. R., \& Hicks, R. (1987). Gait patterns in spastic hemiplegia in children and young adults. Journal of Bone and Joint Surgery, 69, 437-441.

Woollacott, M. H., Burtner, P., Jensen, J., Jasiewicz, J., Roncesvalles, N., \& Sveistrup, H. (1998). Development of postural responses during standing in healthy children and children with spastic diplegia. Neuroscience and Biobehavioral Reviews, 22, 583-589. 


\section{VLIV HIPOTERAPIE NA CHŮZI U OSOB SE SPASTICKOU FORMOU DĚTSKÉ MOZKOVÉ OBRNY}

(Souhrn anglického textu)

VÝCHODISKA: Poruchy motoriky zejména v oblasti chůze jsou běžné téměř u všech forem dětské mozkové obrny. Prostřednictvím pohybu hřbetu koně jsou pacienti vystaveni proprioceptivní stimulaci, lze tedy očekávat zlepšení v provedení chůze.

CÍLE: Cílem studie bylo určit vliv hipoterapie na chůzi u pacientů se spastickou formou dětské mozkové obrny. METODA: Studie se zúčastnilo 11 osob (věk $14,3 \pm 4,8$ let, výška 148,2 $\pm 17,6 \mathrm{~cm}, \quad$ hmotnost $43,3 \pm 20,2 \mathrm{~kg}$ ) se spastickou formou dětské mozkové obrny. Hodnocení chůze bylo provedeno před zahájením a po ukončení týdenního pobytu, $\mathrm{v}$ rámci kterého byla denně indikována hipoterapie. Kinematická data ze tří pokusů u každé osoby byla získána pomocí systému Vicon MX (sedm infračervených kamer, frekven- ce $200 \mathrm{~Hz}$ ). Porovnání pohybu v hlezenním, kolenním a kyčelním kloubu a pohybu pánve před a po hipoterapeutické intervenci byla provedena v programu Statistica (verze 10.0) pomocí Wilcoxonova testu. Pro určení věcné významnosti bylo použito Cohenovo $d$.

VÝSLEDKY: Po ukončení krátkodobé hipoterapeutické intervence bylo zjištěno zmenšení plantární flexe v počátečním švihu $(p<0,05)$, snížení flexe $v$ koleni ve stojné fázi $(p<0,05)$, snížení rozsahu pohybu $\mathrm{v}$ kyčli v sagitální rovině $(p<0,05)$ a snížení úklonu pánve ve frontální rovině $(p<0,05)$. Věcná významnost byla u všech statisticky významných rozdílů nízká.

ZÁVĚRY: Hipoterapie v kombinaci s individuálně stanovenou fyzioterapií může vést $\mathrm{k}$ určitým změnám bipedální lokomoce ve smyslu zlepšení, a tím přispět $\mathrm{k}$ větší soběstačnosti, samostatnosti a nezávislost pacientů s dětskou mozkovou obrnou.

Klícová slova: fyzioterapie, chůze, kůn̆, terapie s využitím koní, dètská mozková obrna. 